NikLai Patrícia Dominika

DOI: 10.15170/DIKE.2018.02.01.07

PhD-hallgató

PTE ÁJK

HORVÁTH Máté

hallgató

PTE ÁJK

\title{
A népbíróságok és a népi ügyészségek magyarországi felállításának nemzetközi jogi alapjai és a népbíróság tevékenysége Pécsett 1945-ben
}

The International Fundaments of the Creation of People's Tribunals and Prosecution Services in Hungary and the Work of the People's Tribunal in Pécs in 1945

The functioning of people's tribunals and people's prosecution service were legally regulated by decrees, which required lay participation because of the political situation after World War II. Many of the general principles of law - for example nullum crimen sine lege - were put in the shades, they focused on the inevitable impeachment of war criminals. In order to implement the impeachment, they created several categories for the comitted crimes: war felony and misdemeanor, as well as felony and misdemeanor against the people. In addition to regulating the activities of peoples's tribunals and prosecution services, the following study gives an insight into the 1945 practice of the People's Tribunal in Pécs. Only a few types of war crimes and crimes against the people appeared before this country court. Among the accused there were a large number of members of the German minority in Hungary, and according to the natural sense of justice - looking back from the 21st century - the punishment seems to be morally excessive in some cases.

Keywords: people's tribunals, people's prosecution services, war criminals, Volksbund

\section{Nemzetközi jogi alapok}

A népbíróságok és népi ügyészségek felállitását elsősorban politikai, nem pedig jogi indokok alapozták meg. 1945-ben a hatalmas méretű háborús pusztításokat és népirtást követően elengedhetetlennek bizonyult, hogy rendkívüli intézkedéseket hozzanak. ${ }^{1}$ A magyar jogtörténetben ezek az intézmények újdonságnak számítottak.

Az Ideiglenes Nemzeti Kormány 1944 decemberében vállalást tett a háborús bűnösök elszámoltatására. Ennek a nyilatkozatnak a nemzetközi jogi keretét a fegyverszüneti egyezmény adta, amely 1945 januárjában, Magyarország és a szövetségesek (Szovjetunió, Egyesült Királyság, Amerikai Egyesült Államok) között jött létre. Ezzel Magyarország elismerte vereségét a háborúban és elfogadta a fegyverszünetre vonatkozó feltételeket. Az egyezmény 5. pontja már előrevetítte a szükséges rendelkezéseket a zsidósággal kapcsolatban is, nem konkrétan a bűnösök felelősségre

\footnotetext{
${ }^{1}$ GYENESEI, A zsidótörvények végrehajtása 172-173.
} 
vonása, hanem a sérelmes állapotok megszüntetése érdekében: „Magyarország kormánya állampolgárságukra és nemzetiségükre való tekintet nélkeül baladéktalanul szabadon bocsátja mindazon személyeket, akik az Egyesült Nemzetek, javára kifejtett tevékenységük.kel kapcsolatban faji származásuk, vagy vallási meggyözódésük következtében örizetben vannak és hatályon kivül helyez minden erre vonatkozó sérelmes törvényt és korlátozást. Minden szü̈kséges inté₹kedést megtesz. annak biz̨tositására, hogy a magyar területen levő összes sqemélyek és menekültek, ideértve a zsidókat is, legalább olyan védelemben részusüljenek, mint saját polgárai." Az egyezmény 14. pontja jelentette a nemzetközi jogi alapot a népbíróságok felállítására, a háborús bűnösök felelősségre vonására: „Magyarors₹ág közre fog müködni a háborús büncselekményekekel vádolt személyek letartóztatásában, az érdekelt kormányoknak való kiszolgáltatásban és az itélkezésben".

\section{A magyar szabályozás}

A nemzetközi vállalás alapján az Ideiglenes Nemzeti Kormány megalkotta a szükséges szabályozást. Az egyezményt az 1945. évi V. törvény, a népbíróságok és a népi ügyészségek múködésének anyagi és eljárásjogi szabályait pedig törvényerejű rendeletek tartalmazták, nevezetesen a 81/1945. (II. 5.) M. E. rendelet (továbbiakban első népbírósági rendelet), az 1140/1945. (V. 1.) M. E. rendelet (továbbiakban második népbírósági rendelet) és két további rendelet [5900/1945. (VIII. 5.) M. E. rendelet, 6750/1945. (VIII. 19.) M. E. rendelet] az egyes részletszabályokról, így például a távollévő terhelt elleni eljárásról. A rendeleteket az 1945. évi VII. törvény emelte törvényerőre. A következőkben a célunk a népbíróságokra és a népi ügyészségekre vonatkozó jogi szabályozás bemutatása a rendeleteken keresztül.

\subsection{A népbírósági jog}

A népbírósági jog számos jogbiztonsági problémát vetett fel. A büntetőjogi garanciákat több helyen sértette: a népbírósági jognak visszaható hatályt tulajdonítottak, továbbá a nullum crimen sine lege klasszikus elvével is ellentétes volt olyan magatartások bủncselekménnyé nyilvánítása, amelyeket korábban törvényi rendelkezés nem nyilvánított annak. ${ }^{3}$ Az elvvel szemben fogalmazta meg az első népbírósági rendelet 1. \$-a, hogy „A jelen rendeletben körülírt büncselekmények az esetben is büntethetök, ba a cselekmény a rendelet életbe léptekor már befejeztetett, s a cselekmény befejezésének. idöpontjában fennállott törvényes rendelkęések alapján az büntethetö nem volt".

Az anyagi jogi hiányosságok mellett a jogorvoslati rendszer is korlátozott volt. Az évek során egyre inkább visszaszorították a lehetőségeket: 1947-ben a fellebbezési jog megszüntetésével semmisségi panaszt vezettek be, amely kizárólag jogkérdésre, nem pedig ténykérdésekre vonatkozott. Az eljárás jogi értelemben vett bizonytalanságát növelte, hogy a tárgyaláson a laikus részvétel dominált, politikai párok és szakszervezetek adták a tagokat.

A népbíróságok jellegét tekintve a Magyar Jogászok Szabad Szakszervezetének Büntetőjogi Bizottsága 1945. november 2. napi ülésén tett megállapításai alapján a népbíróság magyar bíróság,

\footnotetext{
${ }^{2}$ „Megegyezés a Szovjet Sqocialista Köztársaságok Szövetsége, Nagybritannia Egyesült Királysága és Észak-Írország, az. Amerikai Egyesült Államok és Magyarország között létrejött fegyverszüneti szuerzódésröP’, lásd http://www.bibl.uszeged.hu/bibl/mil/ww2/doksi/fszunet.html

${ }^{3}$ GYENESEI, A zsidótörvények végrehajtása 173.
} 
de nemzetközi kötelezettségeinek teljesítése körében a nemzetközi büntetőhatalom delegált fórumaként múködik; ítélkezhet mindazok ügyében is, akik magyar területen követtek el háborús vagy népellenes deliktumot, akiket itt fogtak el, vagy akiket a Szövetséges Hatalmak Magyarországnak kiszolgáltattak. A Bizottság a fennálló helyzetet a következőképpen jellemezte: „A báborus büncselekmények nemzetkö̈ri jellegüek, amelyeknek kollektiv jogtárgya az emberiség békés együttélésének rendje, amelyet a támadó háború alapjaiban rendít meg. Mivel e büncselekmények kriminális tartalma abszolút és univerzális, valamennyi államot érinti közvetve vagy közvetlenül, ezért tehát a politikai menedékjogosultság helyébe az ilyen büntettesek elleni közös kürdelem, a kölcsönös kiadatási kötelezettség lép”. ${ }^{4} \mathrm{~A}$ kortárs vélemény alapján is érzékelhető, hogy olyan helyzet állt fent, amely országokon átívelő együttműködést igényelt. Elsősorban a felelősségre vonás elkerülhetetlenségét kellett hangsúlyozni, nem pedig a jogbiztonságot, amely adott körülmények között torzulhatott. Más kérdés, hogy ez a torzulás később újabb szélsőséges helyzetre szolgáltathatott alapot; azonban a vizsgált időszakban a cél még a háborús és népellenes bűnösök feletti ítélkezés volt.

\subsection{A népbíróságok és a népi ügyészségek felállítása}

1945 első felében először Budapesten, majd ezen kívül több városban népbíróságot állítottak fel (Nyíregyházán, Debrecenben, Szegeden, Gyulán, Balassagyarmaton, Egerben, Miskolcon, Sátoraljaújhelyen, Szolnokon, Kecskeméten, Kalocsán, Baján, Sopronban, Győrben, Esztergomban, Székesfehérváron, Veszprémben, Szombathelyen, Zalaegerszegen, Nagykanizsán, Kaposváron, Pécsett és Szekszárdon). Az első népbírósági rendelet alapján minden törvényszéki székhelyen népbíróságot, ezek mindegyike mellett népi ügyészséget kellett létrehozni, valamint az előbbiek fellebbviteli fórumaként a Népbíróságok Országos Tanácsát, mely mellett a népfőügyész és helyettesei tevékenykedtek. Az intézményrendszer kialakítása nem volt zökkenőmentes. Azonban a nemzetközi kötelezettségvállalás okán sürgették a megvalósítást, így országszerte tájékoztatókat tartottak a felállítandó népbíróságok és a népi ügyészségek munkatársai részére, és a Szövetséges Ellenőrző Bizottság (SZEB) anyagi támogatást is nyújtott. ${ }^{5}$

A népbíróságok keretén belül több tanács működhetett. A népbírósági tanács 5 tagból állt, akiket a Magyar Nemzeti Függetlenségi Frontba tömörült öt politikai párt (Demokratikus Polgári Párt, Független Kisgazdapárt, Magyar Kommunista Párt, Nemzeti Parasztpárt, Szociáldemokrata Párt) javasolt egyenlő arányban. ${ }^{6}$ A második rendelet az Országos Szakszervezeti Tanács számára is lehetőséget biztosított a delegálásra, azaz a tanácsokat 6 főre bővítették.

A bírók kijelölésével kapcsolatban különbséget tettek a büntetett előéletűek között, így nem volt kinevezhető, aki „büntett, nyereségvágyból elkövetett vétség vagy fasiszta jellegü cselekmény miatt elitéltetetè”. Azonban nem tekintették büntetett elóéletűnek azt, „aki fasisztaellenes cselekmény vagy a zsidótörvényekben meghatározott valamely cselekmény miatt itéltetett el' ${ }^{7}$ Ezzel a rendelkezéssel azt érték el,

\footnotetext{
4 Népbírósági Közlöny 1945/1. (1945. november 8.) 13-15., idézi: PAPP, Forradalmak és népbíróságok, http://archivum.kanizsaujsag.hu/hirek/12460/dr-papp-attila-forradalmak--nepbirosagok

5 PAPP, Forradalmak és népbíróságok, http://archivum.kanizsaujsag.hu/hirek/12460/dr-papp-attila-forradalmak-nepbirosagok

6 81/1945. (II. 5.) M. E. rendelet 39.S

7 81/1945. (II. 5.) M. E. rendelet 39. S
} 
hogy azok, akik ellen a fasiszta törvények irányultak, akiknek a megelőző években jogaik csorbultak, részt vehessenek a felelősségre vonásban. Emellett a differenciálás érzékeltette a népbíróságok rendeltetését is, hiszen éppen a megjelölt cselekmények is alapot jelenthettek arra, hogy a népbíróság eljárjon.

A tanácsok egyedüli szakmai tagja a vezetőbíró volt, aki a tárgyalást vezette illetve felvilágosítást nyújtott a tanács tagjainak az alkalmazható jogforrásokról, a kiszabható büntetési nemekről és azok mértékéről. Az ítélet meghozatalába azonban nem szólhatott bele, szavazati joga nem volt.

\subsection{A népbíróságok és népi ügyészségek müködése}

A népbíróság előtt a vádat a népügyész képviselte. A népügyészeket és azok vezetőit az igazságügyi miniszter nevezte ki a bírói és ügyvédi vizsgával vagy szükség esetén jogtudori oklevéllel rendelkező személyek közül a helyi nemzeti bizottság ajánlása illetve meghallgatása után. Az igazságügyi miniszter a népügyészeket bármikor felmenthette. ${ }^{8} \mathrm{~A}$ második rendeletet követôen a népügyészeket közvetlenül a pártok jelölték. Ez alapján láthatjuk, hogy bár szakmai követelmények voltak előírva a pozíciók betöltésére, teljes egészében politikai befolyás érvényesült felettük.

A népügyész feljelentést csak abban az esetben vehetett figyelembe, ha abban a feljelentő pontos lakcímét feltüntette és azt alá is írta. A hiányos vagy hamis név alatt tett vagy nyilvánvalóan alaptalan feljelentést figyelembe venni nem volt szabad. Szóbeli feljelentésről a népügyész jegyzőkönyvet vett fel, amely a feljelentő nevét és lakcímét, a feljelentés alapját képező tényeket és a vonatkozó bizonyítékokat tartalmazta. A jegyzőkönyvet a feljelentővel alá kellett iratni. ${ }^{9}$

A háborús vagy népellenes búncselekményt elkövető bármely személy fölött kizárólag a népbíróság ítélkezhetett. A népbíróság jogköre kiterjedt polgári személyekre és a fegyveres erő tagjaira (ideértve a rendőrséget és a csendőrséget is), valamint a magyar állam területén elfogott vagy a magyar államnak kiadott személyekre, tekintet nélkül azok állampolgárságára, továbbá fiatalkorúakra is. ${ }^{10}$ Miniszterek és korábbi miniszterek sem mentesültek az eljárás alól, nem adott tehát alapot a népbírósági eljárás alóli kivételezésre, hogy az elkövető milyen minőségében követte el a háborús vagy népellenes bűncselekményt, sőt, egyes esetekben kifejezetten a kormány tagja szerepelt elkövetőként a tényállásokban.

\subsection{Kiszabható büntetések}

A népbíróság által kiszabható büntetések a következők voltak: halál, fegyház, börtön, fogház, internálás (6 hónaptól 2 évig), vagyonelkobzásig terjedhetô pénzbüntetés, állásvesztés vagy foglalkozástól való eltiltás, politikai jogok gyakorlásának felfüggesztése, továbbá fegyelmi jellegű büntetések. Ezek főbüntetések voltak, valamint a vagyonelkobzás, pénzbüntetés, állásvesztés vagy foglalkozástól eltiltás, politikai jogok gyakorlásának felfüggesztése mellékbüntetésként is kiszabható

\footnotetext{
8 81/1945. (II. 5.) M. E. rendelet 24. S

${ }^{9} 81 / 1945$. (II. 5.) M. E. rendelet 31. S

$1081 / 1945$. (II. 5.) M. E. rendelet 20-23. SS
} 
volt. ${ }^{11}$ A második népbírósági rendelet az internálás helyett bevezette főbüntetésként a kényszermunkát, amely életfogytig vagy határozatlan időre volt kiszabható. A rendelet a politikai jogok gyakorlásának felfüggesztését mint mellékbüntetést kötelezővé tette minden büntetés kiszabása esetére. Továbbá, ha a bűncselekmény következtében a sértett vagy jogutódja válságos helyzetbe jutott, a népbíróság ítéletében a megfelelő vagyonú vagy jövedelmú elítéltet a nem vitás kárnak vagy hányadának megtérítésére kötelezhette. ${ }^{12}$

Kegyelmezésre szűk körben, de volt lehetőség, ennek joga a Nemzeti Főtanácsot illette, amely határozatát az igazságügyi miniszter javaslatára hozta meg. Ennek csak halálbüntetés esetében és csak az elítéltnek vagy védőjének kérelmére volt helye. A népbíróság által kiszabott halálbüntetés kegyelmi úton életfogytiglani, vagy 10 évtől 15 évig terjedő, határozott időtartamú fegyházbüntetésre volt átváltoztatható. ${ }^{13}$ A második népbírósági rendelet ezt aképpen módosította, hogy a halálbüntetés életfogytig tartó kényszermunkára vagy testi alkalmatlanság esetében életfogytig tartó fegyházra volt átváltoztatható. ${ }^{14}$

\subsection{Háborús és népellenes bünösök}

\subsubsection{Háborús bünösök kategóriái}

A népbíróságok elé tartozó tényállásokat az elkövetői oldalról megközelítve írták le, így megkülönböztettek háborús bűnöst, népellenes bűntettben bűnöst, valamint népellenes vétségben bűnöst. Közös jellemzőjük, hogy mindet hivatalból üldözendőnek minősítették.

Az első népbírósági rendelet a háborús bủnösök leírásával állapította meg a legsúlyosabb háborús bűnöket, ezeket kétszer 5 csoportra (11. \és 13. \) osztotta súlyosságuk és a hozzájuk rendelt büntetési tétel alapján. A 11. \alapján az első csoportba tartoztak azok a vezetők, akik a második világháború Magyarországra való kiterjesztését illetve az ország háborúba sodródását elősegítették („1. aki az 1939. évi háborúnak. Magyarországra való kiterjedését, vagy Magyarországnak a báborúba mind fokozottabb mértékben történt belesodródását vezetö állásban kifejtett tevékenységével vagy

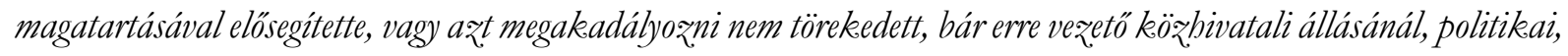
közgazdasági, közéleti szerepénél fogva módja lett volna”). A második csoportba tartozott a kormány, az országgyűlés tagjai és vezető közalkalmazottak, akik jogalkotási tevékenységük során mûködtek közre a háborúba sodródásban (,2. aki mint a kormány, országgyülés tagja vagy mint vezetố állást betöltő közalkalmazott kędeményezóje, vagy bár a következményeket elöre láthatta, részese volt olyan határozat bozatalának, amely a magyar népet az. 1939. évben kitört világháborúba sodorta”). A harmadik kategória a fegyverszünet megkötését megakadályozni igyekvőket foglalta magába (,3. aki a fegyverszünet megkötését eröszakkal vagy befolyásának kihasználásával megakadályozni igyekezett”). A negyedik a nyilas mozgalomban való részvétel különböző eseteit sorolta fel („4. aki vežtô jellegü cselekményével a nyilas mozgalomnak segitséget nyújtott a hatalom megszerzésére irányuló lázadáshoz, a hatalom megtartásához, vagy aki e hatalom megszerzése után kapott kinevezés alapján a nyilas kormányzatban, közigazgatásban vagy honvédelem

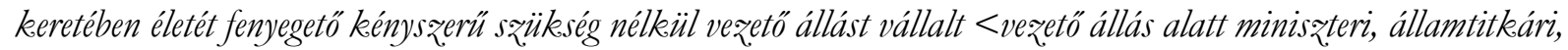

\footnotetext{
$1181 / 1945$. (II. 5.) M. E. rendelet 3. S

12 1140/1945. (V. 1.) M. E. rendelet 1. S

13 81/1945. (II. 5.) M. E. rendelet 7. S

14 1140/1945. (V. 1.) M. E. rendelet 3. \
} 
fö́spáni, föpolgármesteri, hadseregparancsnoki, hadtestparancsnoki vagy hasonló fontosságú állást kell érteni>"). Az ötödik a lakossággal szembeni kegyetlen bánásmód eseteit tartalmazta (,5. aki a megszállott területek lakosságával vagy a hadifoglyokkal való bánás tekintetében a háborúra vonatkozó nemzetközi jogszabályokat súlyosan megsértette, vagy a visszacsatolt területek lakosságával a reá bizott hatalommal visszaélve kegyetlenkedett, vagy aki általában felbujtója, tettese vagy részese volt emberek törvénytelen kivégzésének vagy megkinzásának”). A második rendelet az 5. pontot kiegészítette azzal, hogy akár belföldön, akár külföldön elkövetett cselekményeket büntetni rendelte, továbbá hozzáfüzött egy 6. pontot is azokról, akik sajtótevékenységük folytán járultak hozzá a háborúba való belépéshez, annak folytatásához („,6. aki nyomtatványban (bármilyen módon sokszorositott iratban), gyülekezęt elött elmondott beszédben vagy rádió útján huzamosabb idön át olyan állandó jellegü és folyamatos tevékenységet fejtett ki, amely alkalmas volt arra, hogy az ország háborúba lépése, illetöleg a háború fokozottabb mértékben való folytatása érdekében a kö̊felfogást jelentös mértékben befolyásolja, és az országra káros irányba terelje”). E föbb csoportokba tartozókra kiszabható volt halálbüntetés, kivéve a 2. pontot és az 1. pont második fordulatát („ą̧t megakadályozni nem törekedete’), amelyek esetében 10 évtől 15 évig terjedő fegyház volt a népbíróság által kiszabható legsúlyosabb büntetés. ${ }^{15}$

A 13. S tovább differenciálta a háborús bűnösök kategóriáit, ezekhez enyhébb büntetéseket rendelt. Így háborús bűnösnek számított az is „1. aki nyomtatványban (bármilyen módon sokszorositott iratban), gyülekeezet elött elmondott beszédben vagy rádió útján a háború fokozottabb mértékben való folytatására izgatott”, (a második rendelet bővítette „a háborúba lépésre iəgatote’ fordulattal); „2. aki valamilyen katonai jellegü alakulatnak személy vagy vagyontárgy ellen elkövetett eröszakos cselekményhez segitséget nyújtott; 3. aki nem vezetó jellegü cselekményével a nyilas mozgalomnak segitséget nyújtott a hatalom megszerzéééhez, vagy megtartásához, vagy aki e hatalom megszerzése után kapott kinevezés alapján a nyilas körigazgatásban vagy bonvédelem keretében önként a 11. $\int$ 4. bekezzdésében fel nem sorolt egyéb fontos állást vállalt; 4. aki magyar állampolgár létére a német hadsereg vagy biz̨tonsági szolgálat (SS, Gestapo stb.) kötelékébe lépett; 5 . aki valamilyen német alakulatnak a magyarság érdekeit sértö adatokat szolgáltatott, vagy mint besúgó müködött; 6. aki a báborús birverés szolgálatában jelentôs szellemi munkát végzett’'. A módosító második rendelet ezt is kiegészítette egy 7. ponttal: „7. aki bármilyen formában olyan tevékenységet fejtett vagy fejt ki, illetöleg mozditott vagy mozdit elö, amely a népek háború utáni békéjének vagy együttmüködésének megnehęitésére vagy megbontására, avagy nemzetközi viszály elöidézésére alkalmas". Büntetésük 1 évtől 5 évig terjedő szabadságvesztés börtön végrehajtási fokozatban, súlyosabb esetekben azonban ezen kategóriákba tartozó személyekre is kiszabható volt 10 évtôl 15 évig terjedő fegyházbüntetés. Halálbüntetéssel voltak sújthatók, akik magyar állampolgár létükre a német hadsereg vagy biztonsági szolgálat kötelékébe léptek, ha e cselekményük illetve az e szervekben való szolgálatuk eredményeképpen magyar állampolgár halálát okozták, a magyar honvédség ellen harcoltak, vagy fegyveres erőszakkal megakadályozták, hogy egyesek vagy csapatok a Vörös Hadsereghez átálljanak, emellett azok is, akik rendszeresen vagy jutalom ellenében valamilyen német alakulatnak a magyarság érdekeit sértő adatokat szolgáltattak, vagy besúgóként múködtek. A második rendelet a háborús bűnösök mindkét felsorolására (11. \ és 13. §) vonatkozóan emelte a büntetési tételeket és súlyosabb büntetési nemeket határozott meg. ${ }^{16}$

\footnotetext{
15 81/1945. (II. 5.) M. E. rendelet 11-12. SS; 1140/1945. (V. 1.) M. E. rendelet 6-7. SS
}

16 81/1945. (II. 5.) M. E. rendelet 13-14. SS; 1140/1945. (V. 1.) M. E. rendelet 8-9. SS 


\subsubsection{Népellenes büntett és népellenes vétség}

A népellenes bűnösök kategóriája elsősorban közalkalmazottak tevékenységére vonatkozott, ezen belül az első népbírósági rendelet három csoportot különböztetett meg: „Népellenes büntett 1. a minisztériumnak, az orsqággyülésnek az a tagja vagy az a vezetó állást betölto” közalkalmazott, ki a nép érdekeit súlyosan sértö jogszabály kezdeményezóje volt, vagy annak meghozatalában tudatosan rész̨t vett; 2. aki az 1939. évi szeptember hó 1. napját követô idöben közhivatali ténykedése során a nép egyes rétegei ellen irányuló törvények. és rendeletek végrehajtásában a számára elöirt ténykedést túlhaladva olyan tevékenységet fejtett ki, amely a személyes szabadságot vagy a testi épséget veszélyeztette vagy sértette, vagy egyes személyek vagyoni romlását elósegitette; 3. az. a joghatósággal biró közalkalmazott, aki követkęetesen népellenes, fasisztabarát hivatali müködést fejtett kì". Elkövetőire 2 évtől 5 évig terjedő börtön, az első pont megvalósulása esetén 5 év fegyházbüntetés volt kiszabható. ${ }^{17} \mathrm{~A}$ második népbírósági rendelet a népellenes bűntett körét is bővítette: „4. aki nyomtatványban (bármilyen módon sokszorositott iratban), gyülekęęt elött elmondott beszédben vagy rádió útján huzamosabb idön át olyan állandó jellegü és folyamatos tevékenységet fejtett ki, amely alkalmas volt arra, hogy a fasiszta és a demokráciaellenes irányzatok elterjesztése és megerösitése végett vagy a faji és felekezeti gyülölet felkeltése, illetöleg ébrentartása céljára a köafelfogást jelentös mértékben befolyásolja, és az országra káros irányba terelje; 5. aki a fasiszta és a demokráciaellenes törekvéseknek vagy a társadalom egyes rétegei üldözésének célját szolgáló bivatalos sz̧erv, párt vagy társadalmi szervez̧et besúgójaként müködött, vagy annak számára adatokat szolgáltatott;

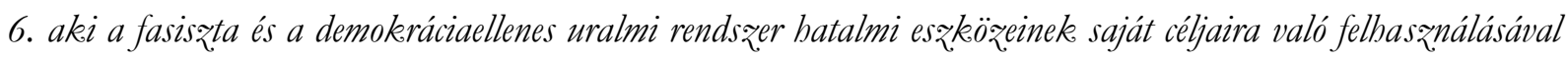
szemérem, vagyon vagy személyes szabadság elleni büncselekményt követett ep'. ${ }^{18}$

Az első népbírósági rendelet még megkülönböztette a népellenes bűntettektől a népellenes vétséget, ezeket 5 csoportra osztotta: „Népellenes vétségben bünös az 1. aki a 15. 』2. (népellenes bűntett 2. pontja) pontjában irt cselekmények elkövetését megakadályozni nem igyekezett, bár ez törvényes hatáskörben módjában állott volna; 2. aki fasiszta, demokráciaellenes pártban fejtett ki kevésbé jelentös, de még vezetố jellegü tevékenységet; 3. aki nyomtatványban (bármilyen módon sokszorositott iratban), gyülekezet elött, rádió útján vagy egyébként nyilvánosan népellenes vagy demokráciaellenes intézkeedések meghozatalát sürgette, vagy a meghozottakat feldicsérte; 4. aki kénysz̨erü szü̈kség nélkü̈l a nép-vagy demokeráciaellenes hírverés szolgálatába szegödött; 5. aki fenyegetô" magatartásával fasiszta- (nyilas-, német-, báború-) ellenes vélemény nyilvánitását akadályozta". A népellenes vétséghez enyhébb büntetések kapcsolódtak: a 1., 4. és 5. pont esetén egy év fogház, a 2. és 3. pont esetén egy év internálás. ${ }^{19} \mathrm{~A}$ második rendelet megszüntette a népellenes vétség kategóriáját, helyette az említett bủncselekmények - továbbiakkal bővülve - szintén népellenes bűntettnek számítottak. 20

\subsection{Fellebbezés}

Fellebbezésnek szűk körben volt helye a vádlott részéről a népbíróság halálbüntetést, teljes vagyonelkobzást vagy állásvesztést kimondó, háromévi szabadságvesztés büntetést, illetve 20.000 pengő pénzbüntetést meghaladó ítélete ellen. A népügyész bármely ítélet ellen élhetett

\footnotetext{
17 81/1945. (II. 5.) M. E. rendelet 15-16. \$S

18 1140/1945. (V. 1.) M. E. rendelet 10. S

19 81/1945. (II. 5.) M. E. rendelet 17-18. SS

20 1140/1945. (V. 1.) M. E. rendelet 12. \
} 
fellebbezéssel, akár a vádlott javára, akár terhére. A vádlott által indított fellebbezésbe is becsatlakozhatott, de ebben az esetben csak a vádlott terhére. ${ }^{21}$

A népbíróságok jogorvoslattal megtámadott ítéleteit a Népbíróságok Országos Tanácsa bírálta felül, amely öttagú tanácsokban járt el. A tanácsok számát az igazságügyi miniszter határozta meg. Összetétele szintén politikai jellegú volt: a korábban említett politikai pártok delegálták a tagokat, azonban szakmai követelményként bírói és ügyvédi vizsga volt előírva. Elnök vezetése alatt állt, akit az igazságügyi miniszter nevezett ki. A Tanács a következőképpen dönthetett a fellebbezésről: az előterjesztést figyelmen kívül hagyja; bizonyítást rendel el, és annak felvételére tárgyalást tűz ki, saját bíráját kiküldi, valamelyik bíróságot megkeresi; a népbíróság ítéletét feloldja és az ügyet újabb eljárás végett ugyanazon vagy az általa kijelölt más népbírósághoz megküldi; valamint a népbíróság ítéletét a vádlott javára megváltoztatja. A Népbíróságok Országos Tanácsa előtt a vádat a népfőügyész vagy helyettese képviselte. Népfőügyész vagy helyettesei csak bírói és ügyvédi vizsgát tett egyének lehettek, akiket az igazságügyi miniszter javaslatára a kormány nevezett ki. A népföügyész a népügyész által bejelentett fellebbezést vagy csatlakozást visszavonhatta. ${ }^{22}$

\section{A Pécsi Népbíróság tevékenysége 1945-ben}

\subsection{A jellemző ügytípusok}

A népbírósági rendeletekben büntetni rendelt háborús bűntettet vagy népellenes bűntettet illetve vétséget megvalósító tényállások közül a Pécsi Népbíróság előtt 1945-ben folyamatba tett 875 ügy²3 között messze nem mindegyik bűncselekménytípus jelent meg. A háborús bűntettek között legnagyobb számban olyan ügyek szerepeltek, melyekben a terhelt a német katonai csapatok valamelyikében szolgálatot teljesített, vagy legalábbis besorozták egy Waffen-SS alakulatba. Az ilyen ügyek ítéleteinek indokolásában a következő fordulat olvasható: „A német véderö által kiadott behivónak eleget téve magyar állampolgár létére a német haderö kötelékébe lépett". Tényleges harci tevékenység nem kellett ahhoz, hogy a tényállás megvalósuljon, már az is elegendő volt, hogy a vádlott a seregbe bevonult, ezzel eleget téve a behívó parancsnak.

Az 1945-ben folyamatba tett ügyek között a népellenes bủntett vádjával indított perek is szép számban szerepeltek. A Pécsi Néptörvényszék illetékességi területéhez tartozó Baranyában jelentős számú német kisebbség24 élt a két világháború közötti időszakban is, ami hozzájárulhatott ahhoz, hogy a népellenes bűntett vádjával indított ügyek vádlottjai között sok magyarországi német volt. Jellemző, hogy a bíróság népellenes bủntett elkövetésében búnösnek nyilvánította a terheltet akkor is, ha csupán tagja volt a Volksbundnak (Magyarországi Németek Népi Szövetsége) anélkül, hogy ott bármiféle fontosabb feladatot ellátott volna. A terheltek rendszerint azzal védekeztek,

\footnotetext{
$2181 / 1945$. (II. 5.) M. E. rendelet 53. \

22 81/1945. (II. 5.) M. E. rendelet 54-62. \$S

${ }^{23}$ A tanulmány 250 ügy áttekintése alapján készült.

${ }^{24}$ A német kisebbség Magyarország népességi adatai szerint 1930-ban a legmagasabb számban Baranyában volt jelen (34,7\%). Az 1941. évi népszámlálási adatok szerint Baranyában305.584 fő élt, ebből 168.662 volt magyar, 105.556 német, 230 szlovák, 577 román, 39 ruszin, 4.706 horvát, 12,245 bunyevác, 8.225 szerb, 922 vend, 3.988 cigány, 16 jiddis vagy héber valamint 418 egyéb anyanyelvű személy élt. Baranyának az országhatáron kívül eső területén ugyan ezek az arányok mutatkoztak: 51.781 főből 18.648 volt magyar, 14.238 német, 113 szlovák, 420 román, 26 rutén, 2.266 horvát, 6.226 bunyevác, 7.813 szerb, 892 vend, 935 cigány, 15 héber illetve jiddisch és 189 egyéb anyanyelvű személy élt. Mindezek alapján tehát a németek létszáma Baranyában 1941-ben is $30 \%$ felett volt.
} 
hogy a Volksbund-tagok különböző de facto „privilégiumokat’ kaptak, és ezek reménye motiválta őket a belépésre. (Ilyen előny volt például az, hogy több nyersanyagot tudott beszerezni az adott gyáros, mint azt a tagság nélkül tehette volna.)

A Volksbund a magyarországi német kisebbség szervezete, a Harmadik Birodalom érdekeinek képviselője volt Magyarországon. Az 1940-es évek elejére a Volksbund kiterjedt iskolahálózattal és szervezetrendszerrel rendelkezett, melyeket nemzetiszocialista és antiszemita szellemben irányítottak. Önvédelmi és rendfenntartó alakulatokat is létrehoztak. 1940-tôl kezdve a Volksbund illegális toborzást is végzett a Waffen-SS-be, majd 1942 februárjában a Bárdossykormánnyal való megegyezés alapján a Német Birodalom jogot nyert SS-önkéntesek verbuválására, és ebben a toborzásban a Volksbund nagy szerepet játszott. Körülbelül 20.000 magyarországi német került így az SS kötelékeibe. Magyarország német megszállása (1945. március 19.) után a magyar kormány hozzájárult ahhoz, hogy német nemzetiségú állampolgárai 17-62 év között a német hadsereg kötelékében teljesítsenek szolgálatot. A Volksbund vezetői a végsőkig kitartottak a náci

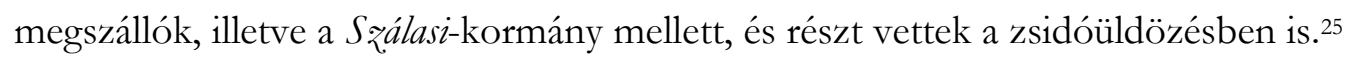

Az 1945-ben a Pécsi Néptörvényszék (azaz nem a fontos állami hivatalok székhelyén, hanem vidéken múködő különbíróság) előtt folyamatba tett perek között a bűncselekmény típusát és a terhelt származását tekintve is világos, hogy itt nem a vezető állami tisztségviselők háborús vagy népellenes tevékenységéről, hanem a „kisemberek” bűneiről mondtak ítéletet, és ezek között - messze nem kizárólagosan, de nagy számban - a német kisebbséghez tartozó elkövetőkről. Mindezek szemléltetésére az alábbiakban négy különböző jogesetet mutatunk be.

\subsection{Király László háborús bűntette ${ }^{26}$}

Király Lászlót a Pécsi Néptörvényszék 1945. április 27-én háborús bűntett miatt kötél általi halálra ítélte. A terhelt 1910-ben született. Büntetlen előéletű, két gyermekes családapa volt, aki 1928-tól szolgált a hadseregben. Hivatásos tiszthelyettes, honvédtörzsőrmester volt. Az eljárás idején az állandó lakhelye Pécsett volt. Származását tekintve magyar volt, aki a római katolikus egyházhoz tartozott. Nyilatkozata szerint megértette, hogy mivel gyanúsították, de nem vallotta magát bűnösnek.

1942 júliusában a százada Dimitrijewka községben állomásozott. Polgári asszonyok jelentették, hogy az ott elszállásolt orosz foglyok fellázadtak és le akarják fegyverezni az ôrséget. Ezért segítséget kértek. A községben sok partizán volt. A lakosság attól félt, hogy kellemetlen helyzetbe kerülnek akkor, ha sikerül a foglyok lázadása és így csatlakoznak a helyi partizánokhoz. Terhelt - a jelentést követően - a község bírájával, egy századparancsnokkal és két asszonnyal azonnal a helyszínre ment. Odaérve az asszonyokat megkérték, hogy mutassák meg, hogy ki a lázadás értelmi szerzője. Ugyanarra a fogolyra mutatott mindkét nő, akit ezután kihallgattak. Kertelés nélkül beismerte, hogy ő akarta rábírni társait arra, hogy fegyverezzék le az őröket, öljék meg ôket és szökjenek át a partizánokhoz. A századparancsnok parancsot adott arra, hogy egy félreeső helyen a terhelt lője agyon a foglyot. A parancsnak engedelmeskedve két másik emberrel

\footnotetext{
${ }^{25}$ Lásd bővebben SEEWANN, A magyarországi németek 316-334.

${ }^{26}$ MNL BML XXV.8 2/1945 Nb. I. 2/1945-5.
} 
együtt elvezették a foglyot, majd a terhelt hátulról tarkón lőtte. Ezután visszament az irodába és jelentette Tarján Jórsef főhadnagynak, hogy végrehajtotta a parancsot.

Király Lász̧ó a vallomását később jelentôs mértékben megváltoztatta. Ekkor már azt állította, hogy nem ő lőtte le szolgálati pisztolyával a foglyot, hanem átadta a fogolyőrség parancsnokának, hogy lőjék agyon ők. Idegességére és az alaptalan vádak folytán keletkezett felháborodására alapozva azt állította, hogy zavarában tette azokat a kijelentéseket a katonai hatóságnál történt kihallgatásakor, hogy az orosz foglyot ô lőtte tarkón. A tanúvallomások és bírói kérdések után végül beismerte, hogy tényleg ô lőtte le a foglyot, ráadásul nem parancsra követte el a tettét, ami súlyosító körülménynek minősült.

A vád szerint továbbá egy erdős helyen, ahol a század több napos orosz hullákat készült eltemetni, a már bomladozó női hullák ruháit terhelt parancsára egy zsidó munkaszolgálatosnak le kellett vennie, ezután pedig terhelt megalázó módon a holttestekbe többször is belelőtt. Ezeket a vádakat a terhelt tagadta. Állítása szerint már körülbelül 10 napos hullákról volt szó, akik nagyon büdösek voltak. Szerinte alaptalan volt a vád, és a tettet csak bosszúból akarták a zsidó tanúk rákenni. Mint később a tanúvallomásokból kiderült, valóban megtette ezt az embertelen halottgyalázást. Hirschler Pálvolt zsidó munkaszolgálatos előadta, hogy ő is részt vett az orosz hullák eltakarításában. A vádlott lehúzatta a nadrágot a hullákról, és beléjük lőtt. A tanú azt állította, hogy mindezt maga látta. Azt is elmondta, hogy durván bánt velük a vádlott, és nagyon kevés élelmiszert kaptak ahhoz képest, hogy mennyit kellett dolgozniuk.

Terhelt állítása szerint az sem felel meg a valóságnak, hogy 1942 augusztusában az orosz áttörés alkalmával azzal az indokkal, hogy a zsidók voltak az áttörés okai, ütötte verte volna ôket. Szerinte a zsidószázad harcos alakulat sosem volt, nem is lett volna lehetőségük betörést feltartóztatni. Azt is tagadta, hogy a zsidó munkaszolgálatosokat okolta a frontáttörés miatt. A három volt munkaszolgálatos zsidó tanú (Hirschler Pál, Schné György és Weisz. István) egymástól függetlenül, kis eltérésekkel azt állította, hogy terhelt az áttörés megtudtával hirtelen haragból a zsidókat szidalmazta és tettlegesen is bántalmazta őket. A vallomásokból világosan érzékelhető, hogy nem kitalált történetről volt szó, hanem - kis eltérésekkel - ugyanazokat a tényeket állították. Grósz. Sándor munkaszolgálatos egy alkalommal a körletben visszamaradt. Amikor ez kiderült, a keretlegénység valamelyik tagja Grósz Sándort a körletből kihúzta, majd a vádlott a sértett nemi szervét és fejét addig rugdosta, amíg az eszméletét vesztette. A bántalmazás során szerzett sérülésekbe az áldozat másnap belehalt. Többször előfordult az is, hogy vádlott a munkaszolgálatosokat rongyosoknak, bugyrosoknak nevezte, és hangoztatta, hogy közülük senki sem megy haza.

A népbíróság a három tanúvallomás alapján „megnyugtatóan bizonyitva látta” a tényállásban leírt cselekmények megvalósulását és a terhelt bűnösségét. Megállapította, hogy „a cselekmények az 1945. évi népbiráskodásról szóló rendelet 6.S-ba ütköző" háborús büntett tényállási elemeit kimerítették". A népbíróság kimondta, hogy „vádlott terbére megállapitott cselekmények súlyosak. Sértik a báború viselésére vonatkozó nemzetközi jogszabályokat. A cselekmény súlyát emeli az is, hogy a cselekmények egy részénél a vezetésére bizott munkaszolgálatosok voltak a cselekmény célpontjai vagy es₹közei”. A cselekmény tárgyi súlya mellett a bíróság súlyosító körülménynek tekintette azt, hogy a vádlott többszörösen és célzatosan követte el cselekményeit, melynek kiviteli módja távol volt minden emberies érzéstől. Enyhítő körülményt 
a bíróság nem talált. Mindezek figyelembe vételével a népbíróság a vádlottat kötél általi halálbüntetésre ítélte.

A kegyelmi tanács az elítéltet egyhangúan kegyelemre ajánlotta. Az indok erre az volt, hogy „a vádlott cselekményei olyan idóben történtek, mikor a korszellem durvasága rendkivüli méreteket öltött, és igy egyéni felelósségét esetleg csökkekenthette a másutt tapasz̨talható sajnálatos esetek elófordulása”. A kegyelmi jog gyakorlása során a tanács egyhangúan életfogytiglani kényszermunkára javasolta átváltoztatni a kiszabott halálbüntetést. A terhelt kegyelemben nem részesült, és ítéletét végrehajtották. Az eljárásban dr. Oltai László volt a tanácsvezetô bíró, valamint Dér József, Borsodi Béla, Vörös István Jámbor Károly, Cqövek Jenố, Achátz̃. Imre népbírák vettek részt.

\subsection{Leher János népellenes büntette ${ }^{27}$}

Leher Jánost népellenes bűntett vádjával vonták felelősségre 1945-ben. A terhelt 1878-ban, Németországban született. Magyarul csak törve beszélt, német anyanyelvű, római katolikus vallású férfi volt, aki feleségét és három gyermekét sajtgyár tulajdonosként tartotta el. Leher büntetlen előéletű volt. Az ügyben a tanácsvezető bíró dr. Pilisy Lász̨ló volt, a népügyész pedig $d r$. Fischer Gyula, míg a védelmet $d r$. Teleki Sándor látta el.

Az 1945. május 22-én felvett jegyzőkönyv szerint Leher János a vádat megértette, bűnösségét azonban nem ismerte el. Állítása szerint a Volksbundba kényszerből lépett be. Pécsen volt sajtgyára, ami 1942 elejéig zavartalanul múködött. Ekkor észrevette, hogy a közellátási minisztériumtól a szokásos havi 20 tonna túró nyersanyagmennyiség helyett csak 1 tonna körüli mennyiséget kap. Mint később megtudta, ez azért volt, mert cégét zsidócégnek nyilvánították. Ez a csekély mennyiség csak havi 100-300 pengő bevételt jelentett a számára és családja számára. Igazolta származását, de nem vették figyelembe, hogy nem volt zsidó. Bonyhád környékén ebben az időben múködött a Volksbundnak egy tejtermék vállalata. Állítása szerint sokan javasolták számára, hogy lépjen be, és végül némi vonakodás után „a kényszerer rávitte a belépésre”. Ez körülbelül 1942 októberében történt. A MILAG nevű vállalattól mindig jó minőségű nyersanyagot kapott, de 1944-ben egy rossz minőségű szállítmány átvétele után már nem rendelt többet tőlük, és ki is lépett a Volksbundból a kényszerítő körülmény megszűnése miatt. Tagdiját a tagsági idôszakban megfizette, bár ez az összeg egyre nőtt az évek folyamán. Nem járt ülésekre, és hangsúlyozza, hogy amint megszúnt a szükséghelyzet, kilépett a tagok közül. Állítása szerint soha nem volt szélsőséges gondolkodásmódja, mindenkit kiszolgált, aki nála rendelt, faji megkülönböztetés nélkül. Említette, hogy az országban való munkálkodása nagy előnyt jelent Magyarország számára, hozzátette, hogy nagyon kicsiben kezdte el a munkát, és ő növelte fokozatosan naggyá a gyárat. Elősegítette Magyarország gazdasági vérkeringését, mert megszerzett külföldi piacokat is termelvényei részére, és sokat szállított külföldre.

A népbíró érdeklődött arról, hogy miért törve beszéli csak a magyart. A válasza erre az volt, hogy az üzem vezetéséhez szükséges szavakat már két hét alatt elsajátította, azonban nem foglalkozott annyira mással, ezért nem volt lehetôsége jobban elsajátítani a magyar nyelvet. Ehhez

\footnotetext{
${ }^{27}$ MNL BML XXV.8 6/1945 Nb. I. 6/1945
} 
hozzájön az is, hogy nem élt társasági életet, és idős ember lévén nehezére esik a tanulás. A terhelt az eljárás idején 65 éves volt.

Tanúk kihallgatása a népügyész szerint felesleges volt, mert a terhelt kihallgatása folytán a tényállás már tisztázódott. Népügyész teljes vagyonelkobzást és politikai jogok 10 évre való felfüggesztését kérte. Az ügyvéd felmentést kért, mert Leher a Volksbundba kényszer hatására lépett be. A Pécsi Népbíróság a terheltet bűnösnek mondta ki a 81/1945 ME rendelet 17. \ helyébe lépő 1440/1945 ME rendelet 12. \-ban meghatározott népellenes bűntettben. Ezek alapján (1440/1945

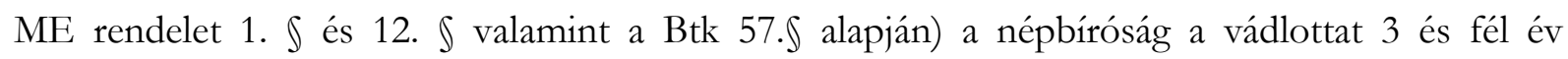
börtönbüntetésre és teljes vagyonelkobzásra, továbbá 10 év hivatalvesztésre és mellékbüntetésként a politikai jogok gyakorlásának ilyen tartalmú felfüggesztésére ítélte 1945. július 24-én.

Az indokolás szerint a MILAG társaság a közellátási minisztérium engedélye nélkül közvetlenül hozta forgalomba a tejtermékeit. Terhelt a Volksbundnak 1942 októberétól illetve novemberétől 1944 szeptemberéig volt tagja. Vádlott azzal védekezett, hogy vele szemben közvetett kényszer alkalmaztatott, miután az üzeméhez szükséges nyersanyagot tőle megvonták 1942-ben. Vádlott ezen védekezését azonban a népbíróság nem fogadta el, mert körülbelül havi 100-300 pengő jövedelme lett volna abból a mennyiségből, amit kapott, és a népbíróság indoklása szerint havi 300 pengő körüli jövedelem biztosította volna (szerény keretek között) a vádlott megélhetését. Büntethetőséget kizáró ok nem állt fenn vádlottal szemben, és mivel a cselekmény kimerítette a rendelkező részben írt bűntett tényállási elemeit, a népbíróság a vádlottat bủnösnek mondta ki. Enyhítő körülményként vették figyelembe magas életkorát és büntetlen előéletét. Súlyosító körülménynek minősült viszont az, hogy terhelt a magyarsággal és a magyar nyelvvel szemben hosszú időn keresztül elutasító magatartást tanúsított. Ezért a népbíróság „a vádlottra alanyi bünösségi fokával és a büncselekmény tárgyi súlyával arányban álló büntetést szabott ki’. Az Országos Tanács a vádlott magas életkorát nyomatékkal értékelte, és úgy találta, hogy a 3 évi és 6 hónapi börtönbüntetés túl szigorú. Ezt a Btk. 91. \-ának alkalmazásával megfelelően mérsékelte.

1947 januárjában a vádlott felesége, id. Leher Jánosné (ügyszámmal nem ellátott beadványában) kérelmezte, hogy bocsássák szabadon a férjét, tekintettel idős korára és rossz egészségügyi állapotára. A kérelme eleinte sikertelennek bizonyult, azonban miután felfolyamodással élt, és az Országos Tanácshoz fordult, 1947. április 22-én Leher János elhagyhatta a büntetés-végrehajtási intézetet.

\subsection{Ifj. Plisz János népellenes büntette ${ }^{28}$}

A terhelt ellen népellenes bűntett elkövetése vádjával 1945. június 23-án indult eljárás, és az ítéletet ez év decemberében hozták meg. Ifj. Plisz János 1910-ben született, német anyanyelvű volt, de beszélt magyarul. Az evangélikus vallású, négy gyermekes férfi bányamunkásként kereste meg a kenyerét. Korábban a német hadseregben teljesített szolgálatot, és nem volt büntetve.

Terhelt vallomásában előadta, hogy 1940-ben lett tagja a Volksbundnak társai és a vasasi vezető rábeszélésére. Nem fejtett ki tevékenységet a szervezetben, a taggyűlésekre viszont járt. Besorozták a Waffen-SS-hez, és behívót is kapott 1944. szeptember 24-re Balatonkenesére. A

${ }^{28}$ MNL BML XXV.8 108/1945 
gyalogságnál kapott kiképzést, ami három hétig tartott. Három nap után a kiképzést Csehországban folytatták, majd novemberben visszatértek Magyarországra, ahol e hó 11-én bevetették őket, a következő napon pedig fogságba esett, ahonnan hazaengedték. A pécsi rendőrkapitányság véghatározatában rendelkezett a vádlott rendőrhatósági őrizet alá helyezéséről, mivel „szabadon mozgása a közrend és közbiz̨tonság szempontjából aggályos és fontos államérdek szempontjából káros”. Az indoklás a következő volt: „Fentnevezett saját beismerése szerint 1940-ben a Volksbund tagja lett, 1944-ben mint SS katona teljesitett szolgálatot elóbb Balatonkenesén, majd Csebszlovákiában, majd visszatért a ceglédi frontra és mint SS katona harcolt a szovjet ellen. Az internálást azért rendelték el, mert alaposan feltehetố volt, bogy szabadon mozgásával tovább folytatná szélsöjobboldali müködését, és ezzel ártana az új demokratikus világrend kialakulásának”. Elrendelték az iratok áttételét a Pécsi Népügyészséghez, mivel „az internálás mint prevenció nem állna arányban az elkövetett cselekmények tárgyi súlyával és a bünösség alanyi fokával'.

A vádlott az elóállításakor beismerte, hogy tagja lett a Volksbundnak, de azt állította, hogy azért lépett be, mert azt mondták neki, hogy ha nem lép be, akkor szanálják a munkájából. Agitatív tevékenységet nem végzett. Végül a vádirat indoklásában rögzítették, hogy „a terbelt beismerését megerösitón nyomozati eljárás egyéb adatai alapján megállapitott tényállás szerint a terbelt kényszerü szüleség nélkül lett tagja a Vasason megalakult Volksbund-szervezetnek. 1944 júniusában alkalmasnak. bizonyult a besorozásra, szeptemberben pedig a német SS kötelékébe lépett Balatonkenesén. Terhelt cselekményeivel a vádkörülírási részben irt büncselekményi tényállási elemeket mindenben kimeritette, ami ąt jelenti, bogy népellenes és háborús büntettet is megvalósitott', ezért volt indokolt ellene a vádemelés. Az ítéletben a terheltet bünösnek mondták ki és 1 év 8 hónap letöltendő börtönbüntetésre, valamint mellékbüntetésként 5 évi hivatalvesztésre és politikai jogai gyakorlásának szintén 5 évig való felfüggesztésére ítélték.

\subsection{Várnagy Elemér népellenes büntette ${ }^{29}$}

Várnagy Elemér 1905. május 19-én született Szabadszentkirályon. A Pécsi Népbíróság előtt népellenes bűntett miatt folyt elllene eljárás. A vád szerint pécsi városi tanácsnok minőségében (azaz joghatósággal bíró közalkalmazott) következetesen népellenes és fasisztabarát hivatali múködést fejtett ki azáltal, hogy hivatali ténykedése során az elé került ügyekben az alsóbb társadalmi osztályokhoz tartozó ügyfelekkel szemben durva bánásmódot és gőgös magaviseletet tanúsított. A város egyik lakótelepén a hétgyermekes Szabó Mihályt és a hatgyermekes Takács Istvánt könyörtelenül kilakoltatta, és az előbbi lakását Friedrich József nyilas párttagnak, az utóbbi lakását pedig egy Volksbund tagnak juttatta. A nyilas mozgalom hatalomra jutását követően hivatalában nyilas köszönést használt, és hivatali íróasztalán nagymennyiségű nyilas röpiratot tartott. Az orosz hadsereg bevonulása előtt a nyugati országrészbe történő menekülés megszervezése körül nagy ügybuzgalmat tanúsított. A közjóléti szövetkezet kezelésében álló népkonyha élelmiszerkészletéből nagy mennyiséget előre a nyugati országrészbe szállíttatott. Gill István tűzoltógépkocsivezetőt és Szekeres István kocsist agyonlövéssel való fenyegetéssel kényszerítette arra, hogy a nyugati országrészbe távozzanak. Személyesen is ellenőrizte a Közjóléti Szövetkezet jármúvének menetkész állapotba helyezését.

${ }^{29}$ MNL BML XXV.8 862/1945 
Várnagy Elemér vádlott nem érezte magát bűnösnek egyik vádpontban sem. Állítása szerint nem felel meg a valóságnak az, hogy durva és gőgös lett volna. Szerinte Esatergár Lajos polgármester, aki „szociális szellemérổ’ volt a városban közismert, meg sem tűrte volna ôt a városházán, a népjóléti ügyosztály vezetését pedig különösen nem bízta volna rá. Hosszan bizonygatta a terhelt, hogy egyik pontban sem bủnös, a tanúvallomások alapján azonban bizonyítást nyert, hogy szélsőjobboldali nézeteket vallva töltötte be tisztségét. Várnagy Elemér vádlott nem érezte magát bűnösnek egyik vádpontban sem. Állítása szerint nem felel meg a valóságnak az, hogy durva és gőgös lett volna. Szerinte Esztergár Lajos polgármester, aki „szociális sz̨elleméróp' volt a városban közismert, meg sem tưrte volna ôt a városházán, a népjóléti ügyosztály vezetését pedig különösen nem bízta volna rá. Hosszan bizonygatta a terhelt, hogy egyik pontban sem bűnös, a tanúvallomások alapján azonban bizonyítást nyert, hogy szélsőjobboldali nézeteket vallva töltötte be tisztségét.

A bíróság megállapította, hogy a terhelt fasiszta illetőleg demokráciaellenes pártokban tagként tevékeny múködést fejtett ki. Az 1944. június 7-én Pécsett rendezett pártvacsorán a párt jelenlévő vezérét Imrédy Bélát üdvözlő beszéddel köszöntötte. Részt vett Ivándy Péter nyilas főispán nyugati országrészbe tett több propaganda körútján, és azokon beszédeket is mondott, sőt a Pécsi Magyar Tudományos Fajvédő Egyesületben is tartott előadást. A bíróság úgy ítélte meg, hogy „,ezek a cselekmények kétrendbeli népellenes büntett tényálladékát valósitják meg, mert a terbelt a szóbanforgó fasiszta és demokráciaellenes pártokban nem maradt meg egyszerü, magát mindentöl távoltartó párttagnak, hanem az egyszerü párttag teljes passzivitásából kilépve a szóbanforgó pártok érdekében a tevékeny múködés fogalma alá esö magatartást tanúsitote’". Várnagyot a Pécsi Népbíróság dr. Kocsis Mibály által vezetett tanácsa főbüntetésként egy és fél év börtönben letöltendő szabadságvesztésre és 3 évi politikai jogvesztésre ítélte. Az ítéletet 1946. május 7-én hirdették ki.

A Várnagy Elemér ellen lefolytatott eljárás - a terhelt jogi felelősségén túl - az erkölcsi felelősség kérdését tekintve is érdekes. Várnagy a terhelt védekezésében a köztiszteletnek örvendő polgármesterre, Esæztergár Lajos hivatkozott, aki akkor is hivatalban volt még, amikor a német megszállást követően (1944. március 19.) a magyar kormány a zsidók elkülönítése, majd deportálás mellett döntött. Ugyan 1944 áprilisában az ún. gettó-rendelet ${ }^{30}$ hatályba lépése után az országban több polgármestere is lemondott és Edmund Veesenmayer német teljhatalmú megbízott többször javasolta a magyar főispánok és polgármesterek cseréjét, Pécs nem tartozott azok közé a városok közé, ahol ez bekövetkezett. Ugyanakkor Nikolits Mihály, Pécs város főispánja a zsidórendeletek megjelenése után lemondott tisztségéről, bár - a Szociáldemokrata és a Kisgazda Párt vezetőinek, közöttük Nagy Ferencnek a kérésére - mégis a helyén maradt. A dél-dunántúli deportálást előkészítő 1944. június 22-i siófoki megbeszélésen, melyre Endre László és Baky László, a belügyminisztérium államtitkárai a helyi közigazgatási és közbiztonsági szervek vezetőit rendelték be, Nikolits nem is vett részt, míg Esztergár jelen volt. Esztergár a gettó-rendelet megjelenését követően, április 30-án Várnagyot bízta meg azzal, hogy Budapestre utazzon a zsidók elkülönítésével kapcsolatos különböző kérdések tisztázása céljából. Bár a gettó-rendelet csak lehetőségként szólt a zsidók elkülönítéséről, Pécs vezetői mégis a gettó létrehozása mellett döntöttek, tekintettel a rendelkezés politikai és közrendészeti jellegére, amelynek Pécsett különös jelentőséget tulajdonítottak a déli

30 A zsidók kényszerlakhelyre költözését elrendelő 1610/1944. M.E. sz. rendelet 1944. április 28 -án jelent meg. Lásd VÖRÖs, A pécsi zsidók, http://www.pecstortenete.hu/index.php/95-tanulmanyok/106-voros-istvan-karoly-a-pecsizsidok-tragediaja-1944-ben 
határ közelsége miatt. ${ }^{31} \mathrm{Az}$ ügyben a munkakapcsolat a polgármester és Várnagy között folyamatos volt, hiszen a zsidóügyek vitelére tanácsnokként őt nevezte ki. ${ }^{32}$ Figyelemre méltó, hogy a humanitásáról és keresztényi érzületéről ismert polgármester nem tartotta antihumánusnak vagy a keresztény értékekkel ellentétesnek azt, hogy 1944. május 15-én levélben forduljon Jaross Andor belügyminiszterhez „A zisidók vagyonából a városok közérdekü céljaira szerzés lehetôvé tétele” tárgyában.33 Esztergár megbecsűlésére hivatkozni akkor, amikor 1945-ben a népi ügyészség ôt magát is nép- és zsidóellenességgel, jobboldali, reakciós politikával vádolta meg, ${ }^{34}$ nem bizonyult hatékony védekezésnek Várnagy részéről. De védekezése azért sem volt releváns a népbírósági perben, mert Esztergárt (a pécsi zsidók deportálása után mintegy három hónappal), 1944 októberében letartóztatták, azaz amikor Várnagy még aktív nyilasként tevékenykedett, a szélsőjobboldal számára a fentiek ellenére is megbízhatatlannak tûnô volt polgármestert már internálták. Szembetűnő, hogy a bíróság csak a terhelt fasiszta illetőleg demokráciaellenes pártokban tagként kifejtett tevékenységét értékelte, annak azonban nem volt jogkövetkezménye, hogy városi tanácsnokként a polgármester megbízására közvetlenül is szerepe volt a pécsi zsidók gettósításában 1944. június 22. előtt, sôt mindez az ügyiratokban szóba sem került.

\section{4. Összegzés}

A népbíróságokat és népi ügyészségeket egy különleges helyzet hívta életre, amely a második világháború pusztító, embertelen következményeiből adódott. Múködésüknek rendeletek adtak jogi keretet, ugyanakkor a politikai helyzet megkívánta a laikus részvételt munkájukban. Az általános jogelvek háttérbe szorultak, és az elkövetők elmaradhatatlan felelősségre vonására koncentráltak. Ezt szolgálta az intézményekre vonatkozó jogi szabályozás szigorú jellege is. A Pécsi Népbíróság 1945. évi ügyei alapján megállapítható, hogy a vidéki bíróság előtt a háborús illetve a népellenes bűncselekményeknek csak némely típusa jelent meg. A fennmaradt ügyiratok alapján a terheltek között feltűnően nagy számban (mintegy 90\%-ban) voltak jelen a Volksbund tevékenységében közvetlenül érintett magyarországi németek, akiknél az eljárás során a fő kérdés jellemzően az volt, hogy a Volksbundba (közvetlen vagy közvetett) kényszer nélkül léptek-e be. A természetes jogérzet szerint - a 21. századból visszatekintve - az ügyek egy töredékében (a fenti négy jogeset közül egyben, ifj. Plisz János perében) erkölcsileg túlzásnak tűnik a büntetés súlya, míg máshol (Vámagy Elemér ügyében) hiányérzet marad a népbírósági jogban büntetni rendelt magatartások körét tekintve.

\footnotetext{
31 VÖRÖS, A pécsi zsidók, http://www.pecstortenete.hu/index.php/95-tanulmanyok/106-voros-istvan-karoly-apecsi-zsidok-tragediaja-1944-ben

32 Mivel 1944. június 22-ig a csendőrségnek a törvényhatósági jogú városban nem volt illetékessége, a rendészeti és közbiztonsági feladatokat ellátó városi rendőrkapitányságot is meg kell említeni, melyen belül a zsidó ügyekért Németh László rendőrfogalmazó felelt. Lásd VÖRÖs, A pécsi zsidók, http://www.pecstortenete.hu/index.php/95tanulmanyok/106-voros-istvan-karoly-a-pecsi-zsidok-tragediaja-1944-ben

33 VÖRÖS, A pécsi zsidók, http://www.pecstortenete.hu/index.php/95-tanulmanyok/106-voros-istvan-karoly-apecsi-zsidok-tragediaja-1944-ben

34 VARGHA, Esztergár 64-70.
} 


\section{Felhasznált források és irodalom}

Megegyezés a Szovjet Szocialista Köztársaságok Szövetsége, Nagybritannia Egyesült Királysága és Észak-Írország, az Amerikai Egyesült Államok és Magyarország között létrejött fegyverszüneti szerződésről (1945. január 20.); http://www.bibl.u-szeged.hu/bibl/mil/ww2/doksi/fszunet.html

81/1945. (II. 5.) M. E. rendelet

1140/1945. (V. 1.) M. E. rendelet

Az 1930. évi népszámlálás. I. rész: Demográfiai adatok községek és külterületi lakóhelyek szerint. Budapest 1932

Az 1941. évi népszámlálás. Demográfiai adatok községek szerint. Budapest 1947

Az 1941. évi népszámlálás. Demográfiai adatok községenként (Országhatáron kívüli terület). Kézirat. Budapest 1990

GYENESEI József: A zsidótörvények végrehajtása Somogy vármegyében - a Kaposvári Népbíróság periratainak tükrében. In: BŐSZE Sándor (szerk.): Újrakezdések. Kaposvár 2005

PAPP Attila: Forradalmak és népbíróságok, http://archivum.kanizsaujsag.hu/hirek/12460/dr-papp-attilaforradalmak-nepbirosagok

SEEWANN, Gerhard: A magyarországi németek története 1860 - 2006. Budapest 2015

VARGHA Dezső: Esztergár Lajos életútja. Pécsi Szemle 2002/4. szám, 64-70.

VÖRÖS István Károly: A pécsi zsidók tragédiája 1944-ben. In: HABEL János (vál. és szerk.): Pécsi levelek 1944-ből. Dokumentumok a „zsidókérdés” pécsi megoldásáról. Pécs 2014, http://www.pecstortenete.hu/index.php/95tanulmanyok/106-voros-istvan-karoly-a-pecsi-zsidok-tragediaja-1944-ben (letöltés: 2018. 07. 01.) 